\title{
IMPACT OF CLIMATE CHANGE ON INDIAN ECONOMY
}

\author{
Dnyandev Eknath Zine \\ Arts, Commerce \& Science College, Sonai.Taq. Newasa, Dits. Ahmednagar- 414105 (M.S) \\ Corresponding Author: dnyandev79@gmail.com
}

\begin{abstract}
:
The entire world is looking towards the outcomes of environmental change and India monetary development. This paper will conceptualize the effects of environmental change on Indian businesses by featuring models over the world. This methodology will control us to embrace reasonable measure(s) to check the negative effects of environmental change on Indian economy. We finish up the paper within the sight of vulnerabilities identified with environmental change example and rebound of created economies.
\end{abstract}

Key words: - Climate change, Indian economy.

\section{INTRODUCTION:}

I think there is no positive effect of environmental change on economies (ecological, value or environment) anyplace on the planet. Atmosphere is dynamic. At that point why we are stressed over environmental change. Since, normal environmental change may take a large number of years. However, the 'Environmental change' we are confronting, the most extreme change in last 420, 000 years, is an unavoidable increment of 2 degree Celsius worldwide temperature by 2050. It is a change in precipitation as well as complete seasons, in temperature variety as well as complete vitality cycle, wind stream as well as complete biodiversity design, and water bodies as well as new political maps. The image is dormant. It is valid in Indian setting as well. Kindly don't get shock!

\section{Effect on Agriculture, Fishery, and Forest.}

As indicated by Sathaye et al (2006) our frameworks are going to confront an expansion of 5.8 degree Celsius by 2100 that will have extreme effect on crop creation, ocean level worldwide hydrological frameworks, and biological systems. It would be principally for tropical zones including India. We have around 700 million country populaces subject to atmosphere touchy financial segments like farming, woods, and fisheries for nourishment and employments. Farming is nature based financial movement. It will bring about enormous misfortune within the sight of changing precipitation or season design. As per Rosenzweig and Parry (1994) creation in the created world profited by environmental change, where as creation in creating countries declined. South Asia will bring about greatest negative effect on yield (Nelson et al, 2009). Harvests would have the option to support such tremendous change. It will prompt intense nourishment lack and more significant expenses. It will turn out to be progressively hard to anticipate the yield under the changing common conditions. That may bring about further change in land-use design which leads to supplanting of horticulture with some other industry. Henceforth, they need to move to the urban work environments as workers. In progressively despicable conditions they may need to function as workers on their own 
territory. It would be monetary cum societal position misfortune for ranch proprietors.

The environmental change will have most unmistakable effect on the ocean level and change in submerged assets. Environmental change will have genuine ramifications for angles, the travel industry, seaside security, and individuals. Under-resourced and creating nations have the least ability to react to environmental change (Hough-Guldberg, 2007). They found that environmental change will apply risk on individuals, framework, and mangroves because of developing wave and tempest impacts. There will be loss of Asian coral reefs which are home of around one-fourth of the yearly fish catch and nourishment to around 1 billion individuals. India has in excess of 7,000 kilometers coastline which bolsters millions' nourishment and business prerequisites. Environmental change can have extraordinary effect on the populace and species endurance. It can take livings of the thousand honest people just to remunerate the advancement occurring elsewhere. Atmosphere sway evaluations utilizing BIOME-3 model and atmosphere projection for the year 2085 shows a move towards wetter timberlands in the northeastern district and drier woods types in the northwestern Area without human impact. Any adjustment in the example of Indian backwoods is a caution for both government and individuals since it cost cash in migration or restoration of individuals and lead to loss of conventional information and culture. Indeed, Indian financial specialist plans for forestation to decrease the carbon discharge. Parikh and Parikh have contended (2002) that timberland ingest carbon just during the development stage. When trees are developed, they will become financial liabilities as far as land aggregation.

Venture for Healthy Economy: Education, Energy, and Ecology
"Individuals engaged with industry regularly allude to an item's 'life cycle.'... We need them to live with us, to have a place with us. In Western culture, individuals have graves, thus do Items... We like to purchase things that are fresh out of the box new, made of materials that are 'virgin.'... We perceive and comprehended the benefit of feeling exceptional, even interesting... What might have occurred, we at times wonder, if the Industrial Revolution had occurred in social orders that underline the network over the individual, and where individuals accepted not in support to-grave life cycle yet in resurrection?" Braungart, M. and McDonough, W. (2009) Michael Braungart and William McDonough have delightfully campaigned the wastefulness of our economies.

At present none has proposed an option of free enterprise (economies). In any event we have a few activities towards 'sound economy.' Healthy economy can be comprehended as a cyclic utilization of restricted assets like blood dissemination in our body through heart. As Jannie M. Benyus talked about that we have a considerable rundown of businesses filling in as conduits yet there are colossal hole for veins to finish the course. The information and reception of dissemination of utilized items and administrations just can decrease the issues of shortage assets and their effective use. How to accomplish that solid economy? Solid economy requires interest in training, vitality and biology.

\section{CONCLUSION:}

Job for instruction to make individuals delicate and minding towards their condition. He discovered training being created in various orders absent a lot of connection and interdisciplinary research. As result each time we break down the circumstance, we see just one face of the issue. Indian instructive establishments expect speculation to grow new trains and to take manageability training at 
ground level particularly in urban regions. Regardless of whether we embrace sustainable assets, to refine and build up the innovation we need to rethink our educational plan and research motivation. Vitality is soul of economies. It causes them to develop, produce and proceed with the cycle. To a great extent Indian economy runs on power or other noninexhaustible wellsprings of vitality. To relieve the effect of environmental change we have to change to inexhaustible wellsprings of vitality like sun oriented, hydro, wind, or warm. Being creating economy, we need green innovations. Furthermore, every time we need to look towards the western countries on high consultancy costs. Again job of training and research is being stressed to create green innovations as per nearby Indian conditions. We have to take some striking choice like Germany to move vitality request towards green and clean vitality options.

To alleviate atmosphere sway we have to put resources into biology. Point is environmental change implies no typical lifecycles. It will assist with observing the measure of assets expended or corrupted to fuel the economy just as, to comprehend the complexities of environmental change on horticulture, fishery, and woods nature for creating economies. Furthermore, India will be from creating status to grew, at some point or another. My fingers are crossed to see the consequences of this move. What India will be? I don't know.

\section{REFERENCES:}

Benyus, J.M. (2002). Biomimicry: innovation inspired by nature. HarperCollins, New York.

Braungart, M. \& McDonough, W. (2009). Cradle to Cradle: re-making we make things. Vintage Books. London.

Hoogh-Guldberg, O. (2007). Coral reefs under rapid climate change and ocean acidification. Science, 318, 1737-1742.

King, D.A. (2004). Climate change science: adopt, mitigate, or ignore? Science 203, 176-177.

Parikh, J.K. \& Parikh, K. (2002). Climate change: India's perceptions, positions, policies and possibilities. Climate Change and Development, OECD.

Rosenzweig, C. \& Parry, M.L. (1994). Potential impact of climate change on world food supply. Nature, 367, 133-139.

Sathaye, J., Shukla, P.R., \& Ravindranath, N.H. (2006). Climate change, sustainable development and India: global and national concern. Current Science, 90 (3), 314-325. 